Hydrogen Production from Biomass via Indirect Gasification: The Impact of NREL Process Development Unit Gasifier Correlations

C.M. Kinchin, and R.L. Bain

Technical Report NREL/TP-510-44868

May 2009 


\section{Hydrogen Production from Biomass via Indirect Gasification: The Impact of NREL Process Development Unit Gasifier Correlations}

Technical Report NREL/TP-510-44868

May 2009

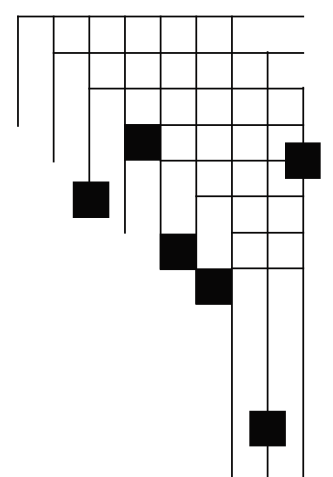




\section{NOTICE}

This report was prepared as an account of work sponsored by an agency of the United States government. Neither the United States government nor any agency thereof, nor any of their employees, makes any warranty, express or implied, or assumes any legal liability or responsibility for the accuracy, completeness, or usefulness of any information, apparatus, product, or process disclosed, or represents that its use would not infringe privately owned rights. Reference herein to any specific commercial product, process, or service by trade name, trademark, manufacturer, or otherwise does not necessarily constitute or imply its endorsement, recommendation, or favoring by the United States government or any agency thereof. The views and opinions of authors expressed herein do not necessarily state or reflect those of the United States government or any agency thereof.

Available electronically at http://www.osti.gov/bridge

Available for a processing fee to U.S. Department of Energy and its contractors, in paper, from:

U.S. Department of Energy

Office of Scientific and Technical Information

P.O. Box 62

Oak Ridge, TN 37831-0062

phone: 865.576 .8401

fax: 865.576 .5728

email: mailto:reports@adonis.osti.gov

Available for sale to the public, in paper, from:

U.S. Department of Commerce

National Technical Information Service

5285 Port Royal Road

Springfield, VA 22161

phone: 800.553.6847

fax: 703.605.6900

email: orders@ntis.fedworld.gov

online ordering: http://www.ntis.gov/ordering.htm 


\section{Abbreviations and Acronyms}

BCL
CO
CO2
DCFROR
H2
H2S
MHSP
NREL
PSA
Scf
TCPDU
TOC
TPI

$\mathrm{BCL}$

$\mathrm{CO} 2$

DCFROR

$\mathrm{H} 2$

HSP

NREL

PSA

TPI

\author{
Battelle Columbus Laboratory \\ carbon monoxide \\ carbon dioxide \\ discounted cash flow rate of return \\ molecular hydrogen \\ hydrogen sulfide \\ minimum hydrogen selling price \\ National Renewable Energy Laboratory \\ pressure swing absorption \\ standard cubic feet \\ Thermochemical Process Development Unit \\ total operating cost \\ total project investment
}

\section{Executive Summary}

NREL developed a new set of empirical gasifier correlations using data collected from the Thermochemical Process Development Unit. The new correlations replaced the old correlations in the Aspen Plus model presented in the Biomass to Hydrogen Design Report (Spath et al. 2005). The new correlations predict a slightly different dry gas composition, although the most significant difference is less char. The new correlations predict $0.10 \mathrm{lb}$ of char per lb of dry feed, whereas the old correlations predict $0.22 \mathrm{lb}$ of char; consequently, a portion of the raw syngas must be diverted to the char combustor to provide the heat necessary for gasification and drying the incoming biomass. The model predicts $2.6 \%$ more final hydrogen product when the new gasifier correlations are used. The new correlations also predict a minimum hydrogen selling price of $\$ 1.24$ per $\mathrm{kg}$ (2002 dollars), which equal to the $\$ 1.24$ per $\mathrm{kg}$ predicted by the old correlations. Using 2007 Biomass Program economic assumptions, the new correlations predict a minimum hydrogen selling price of \$2.14 per kg (2007 dollars). 


\section{Table of Contents}

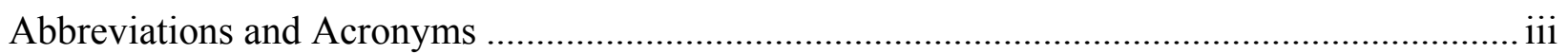

Executive Summary ........................................................................................................ ii

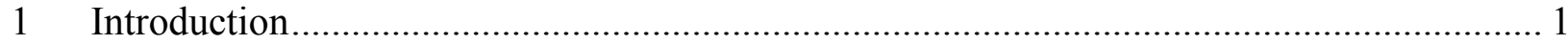

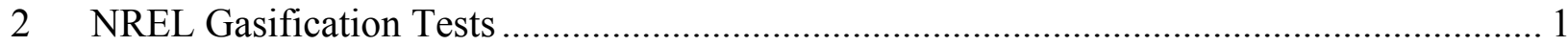

3 Results of Regression Analysis................................................................................... 3

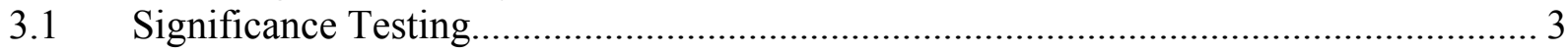

3.2 Regression Results ........................................................................................ 4

4 Comparison of New and Old Correlations....................................................................... 6

5 Results of Wood to Hydrogen Model using New Correlations ............................................ 7

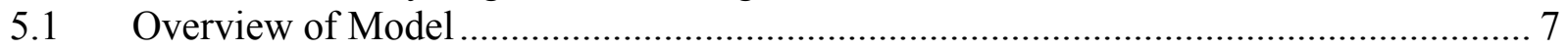

5.2 Results of Goal Case Design with New Correlations ................................................... 9

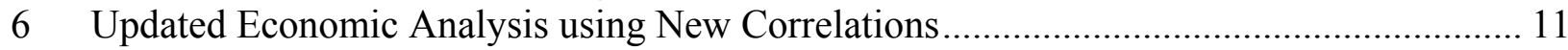

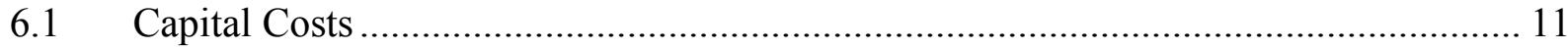

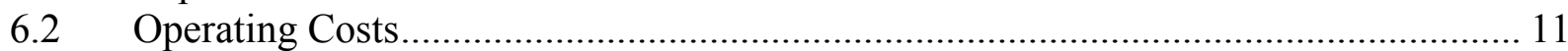

6.3 Discounted Cash Flow Rate of Return Analysis (DCFROR) ..................................... 12

6.4 New Correlations versus Old Correlations in 2002 Dollars ……………................... 12

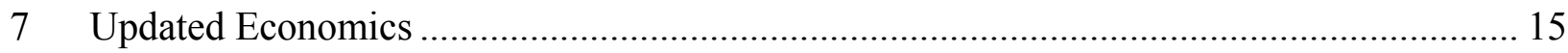

7.1 Economic Results Using 2005 Biomass Program Assumptions.................................. 15

7.2 Economic Results Using 2007 Biomass Program Assumptions.................................... 16

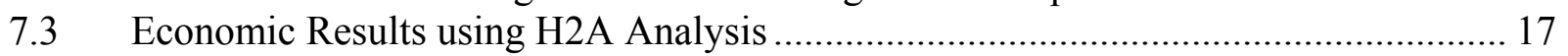

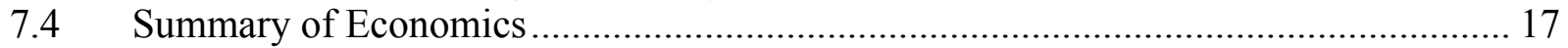

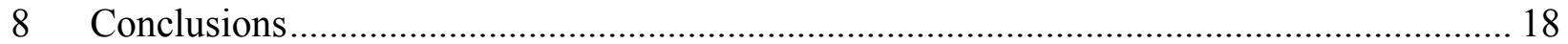

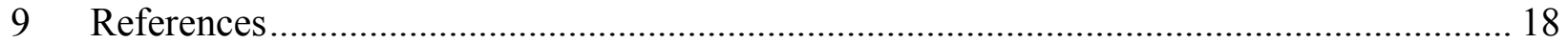

Appendix A. Correlation Values for Equations 1, 2 and 3 ....................................................... 19 


\section{Introduction}

In 2005, the National Renewable Energy Laboratory (NREL) developed an Aspen Plus model to examine the technical and economic feasibility of indirect steam gasification to produce hydrogen from wood (Spath et al. 2005). In the model, the gasifier products were predicted using empirical correlations developed by Bain in 1992 (Bain 1992). The empirical correlations were based on data collected from the Battelle Columbus Laboratory (BCL) 9 tonne/day facility. In 2007 and 2008, NREL conducted gasification tests using various biomass feedstocks for the purpose of developing empirical correlations. The new set of empirical correlations have been generated and assimilated into the Wood to Hydrogen model. This report presents the results of the model using the new correlations and is divided into the following sections:

1. A brief description of the NREL gasification tests

2. Results of the regression analysis used to develop the new correlations

3. Comparison of the new and old correlations

4. Results of the Wood to Hydrogen model using the new correlations

5. Updated economics analysis using new correlations

6. Updated economics using 2005 and 2007 Biomass Program assumptions

7. Updated economics using the $\mathrm{H} 2 \mathrm{~A}$ analysis.

\section{NREL Gasification Tests}

The NREL gasification tests examined the effects of several process variables on the gasifier product yields and compositions (char production rate, tar rates, dry gas composition, etc.). The following process variables were adjusted in the experiments:

1. Feedstock: wheat straw, Vermont wood, corn stover, oak wood, and pine wood

2. Gasification temperature: $600^{\circ} \mathrm{C}$ to $950^{\circ} \mathrm{C}$

3. Steam to biomass mass ratio: 0.33 to 2.0 .

Not all feedstock samples were tested over the entire range of gasification temperatures. Only oak and pine woods were tested at gasification temperatures above $875^{\circ} \mathrm{C}$ and steam to biomass ratios above 1.2. Also, residence time at the maximum gasification temperature was calculated and used as a process variable in the Aspen Plus model, although it was not controlled during the gasification experiments. The NREL gasifier is actually a two stage gasification process, consisting of a fluidized bed reactor with a maximum temperature of $750^{\circ} \mathrm{C}$, followed by an electrically heated thermal cracker capable of temperatures up to $950^{\circ} \mathrm{C}$.

The effects of the adjusted process variables (input variables) listed above were measured in the following product rates and compositions (output variables):

1. Total nitrogen-free dry gas yields, standard cubic feet (scf) per lb of moisture and ash free (MAF) feed 
2. Hydrogen, mol\%

3. Carbon dioxide, $\mathrm{mol} \%$

4. Carbon monoxide, $\mathrm{mol} \%$

5. Methane, $\mathrm{mol} \%$

6. Ethane, $\mathrm{mol} \%$

7. Ethylene, mol\%

8. Acetylene, $\mathrm{mol} \%$

9. Propane, $\mathrm{mol} \%$

10. Propene, $\mathrm{mol} \%$

11. 1-Butene, mol\%

12. 2-c-Butene. $\mathrm{mol} \%$

13. 2-t-Butene, $\mathrm{mol} \%$

14. Carbonyl sulfide, ppmv per lb of dry wood

15. Hydrogen sulfide, ppmv per lb of dry wood

16 . Benzene, $\mathrm{lb}$ per $\mathrm{lb}$ of dry wood

17. Toluene, $\mathrm{lb}$ per $\mathrm{lb}$ of dry wood

18. Phenol, lb per lb of dry wood

19. Cresols, lb per lb of dry wood

20. Naphthalene, $1 \mathrm{~b}$ per $\mathrm{lb}$ of dry wood

21. Phenanthrene, $\mathrm{lb}$ per $\mathrm{lb}$ of dry wood

22. Total tars (sum of all tars except benzene), lb per lb of dry wood

23. Char, lb per lb of dry wood.

It should be noted that components 2 through 15 are reported on a dry, nitrogen-free, tar-free basis. They were measured after tars and water present in the syngas were condensed in scrubbers. Components 16 through 22 are considered tars and were measured prior to the scrubbers.

The purpose of this report is to provide the results of the Wood to Hydrogen Aspen Plus model with updated gasifier correlations; therefore, a detailed description of the experimental procedure used to collect the thermochemical process development unit (TCPDU) data will not be provided here. The detailed experimental procedure and results can be found in the Joule Milestone Report "Pilot-Scale Parametric Gasification of Wood, Switchgrass, and Wheat Straw to Develop Correlations for Input in Process Models" (Phillips 2007) and "Parametric Gasification of Oak and Pine Feedstocks using the TCPDU and Slipstream Water-Gas Shift Catalysts" (Hrdlicka 2008). 


\section{Results of Regression Analysis}

\subsection{Significance Testing}

The data collected during the NREL gasification tests were subjected to a regression analysis using Unscrambler statistical software. The significance of several process variables was first tested. The process variables considered were:

1. Proximate analysis

2. Ultimate analysis

3. Ash composition (base ratio, dolomite ratio, Ca content)

4. Fluid bed temperature

5. Secondary entrained-flow thermal cracker temperature

6. Steam to biomass ratio

7. Residence time.

In addition to the process variables listed above, interactions between most of the process variables as well as squared effects were also tested for significance. All of the process variables were determined to be significant for at least a few of the output variables, and none were determined to significantly affect all output variables, although several process variables were found to be significant more often than others. The process variables that were most often significant, as well as generally the most significant in terms of the highest degree of significance were the following:

1. Ultimate analysis

2. Proximate analysis

3. Gasification temperature (secondary thermal cracker temperature)

4. Steam to biomass ratio

5. Residence time

6. Interactions between gasification temperature, steam to biomass ratio, and residence time

7. Squared effects of gasification temperature, steam to biomass ratio, and residence time.

The significance testing resulted in 18 significant process variables: five ultimate analysis terms (5), four proximate analysis terms (9), gasification temperature (10), steam to biomass ratio (11), residence time (12), three interactions terms (15), and three squared terms (18). A correlation equation requiring eighteen terms suggests over-fitting, but the correlation needs to be sufficiently robust to predict several gasification products (dry gases, tars, char) from a wide variety of feedstocks. If the correlation is asked to predict only dry gases from a single feedstock composition, less than eighteen terms would be required, but this model is expected to be more robust. Also, terms that show very small variation across feedstocks, such as mass percent hydrogen in the ultimate analysis, could arguably be eliminated from the correlations, but other ultimate analysis terms such as the nitrogen and sulfur mass percent make significant contributions to syngas cleanup operating costs. 


\subsection{Regression Results}

After significant effects were determined, a separate regression analysis was run in Unscrambler for each of the output variables (product yields and compositions). The result of the regression analysis was an equation that predicts the production rates or gas composition as a function of the input process variables:

$\mathrm{Y}=\mathrm{B}_{\text {int }}+\mathrm{X}_{\mathrm{M}} * \mathrm{~B}_{\mathrm{M}}+\mathrm{X}_{\mathrm{VM}} * \mathrm{~B}_{\mathrm{VM}}+\mathrm{X}_{\mathrm{FC}} * \mathrm{~B}_{\mathrm{FC}}+\mathrm{X}_{\mathrm{A}} * \mathrm{~B}_{\mathrm{A}}+\mathrm{X}_{\mathrm{C}} * \mathrm{~B}_{\mathrm{C}}+\mathrm{X}_{\mathrm{H}} * \mathrm{~B}_{\mathrm{H}}+\mathrm{X}_{\mathrm{O}} * \mathrm{~B}_{\mathrm{O}}+\mathrm{X}_{\mathrm{N}} * \mathrm{~B}_{\mathrm{N}}$

$+\mathrm{X}_{\mathrm{S}} * \mathrm{~B}_{\mathrm{S}}+\mathrm{X}_{\mathrm{TC}} * \mathrm{~B}_{\mathrm{TC}}+\mathrm{X}_{\mathrm{SB}} * \mathrm{~B}_{\mathrm{SB}}+\mathrm{X}_{\mathrm{RT}} * \mathrm{~B}_{\mathrm{RT}}+\mathrm{S}_{\mathrm{TC}}{ }^{2} * \mathrm{~B}_{\mathrm{TC}}{ }^{2}+\mathrm{S}_{\mathrm{SB}}{ }^{2} * \mathrm{~B}_{\mathrm{SB}}{ }^{2}+\mathrm{S}_{\mathrm{RT}}{ }^{2} * \mathrm{~B}_{\mathrm{RT}}{ }^{2}$

$+\mathrm{I}_{\mathrm{TC}: \mathrm{SB}} * \mathrm{~B}_{\mathrm{TC}: \mathrm{SB}}+\mathrm{I}_{\mathrm{TC}: \mathrm{RT}} * \mathrm{~B}_{\mathrm{TC}: \mathrm{RT}}+\mathrm{I}_{\mathrm{SB}: \mathrm{RT}} * \mathrm{~B}_{\mathrm{SB}: \mathrm{RT}}$

where

$\mathrm{Y}=$ Predicted value of output variable ( $\mathrm{lb} / \mathrm{lb}$ of dry biomass for char and tars, mole percent for dry gases)

$\mathrm{B}_{\text {int }}=$ Intercept term

$\mathrm{X}_{\mathrm{M}}=$ Moisture mass percent of the feed (proximate analysis)

$\mathrm{B}_{\mathrm{M}}=$ Coefficient of moisture term

$\mathrm{X}_{\mathrm{VM}}=$ Volatile matter mass percent of the feed (proximate analysis)

$\mathrm{B}_{\mathrm{VM}}=$ Coefficient of volatile term

$\mathrm{X}_{\mathrm{FC}}=$ Fixed carbon mass percent of the feed (proximate analysis)

$\mathrm{B}_{\mathrm{FC}}=$ Coefficient of fixed carbon term

$\mathrm{X}_{\mathrm{A}}=$ Ash mass percent of the feed (proximate analysis)

$\mathrm{B}_{\mathrm{A}}=$ Coefficient of ash term

$\mathrm{X}_{\mathrm{C}}=$ Carbon mass percent of the feed (ultimate analysis, $\mathrm{wt} \%$ as received)

$\mathrm{B}_{\mathrm{C}}=$ Coefficient of carbon term

$\mathrm{X}_{\mathrm{H}}=$ Hydrogen mass percent of the feed (ultimate analysis, $\mathrm{wt} \%$ as received)

$\mathrm{B}_{\mathrm{H}}=$ Coefficient of hydrogen term

$\mathrm{X}_{\mathrm{O}}=$ Oxygen mass percent of the feed (ultimate analysis, $\mathrm{wt} \%$ as received)

$\mathrm{B}_{\mathrm{O}}=$ Coefficient of oxygen term

$\mathrm{X}_{\mathrm{N}}=$ Nitrogen mass percent of feed (ultimate analysis, $\mathrm{wt} \%$ as received)

$\mathrm{B}_{\mathrm{N}}=$ Coefficient of nitrogen term

$\mathrm{X}_{\mathrm{S}}=$ Sulfur mass percent of feed (ultimate analysis, $\mathrm{wt} \%$ as received)

$\mathrm{B}_{\mathrm{S}}=$ Coefficient of sulfur term

$\mathrm{X}_{\mathrm{TC}}=$ Gasification temperature, ${ }^{\circ} \mathrm{C}$

$\mathrm{B}_{\mathrm{TC}}=$ Coefficient of gasification temperature term

$\mathrm{X}_{\mathrm{SB}}=$ Steam to biomass ratio

$\mathrm{B}_{\mathrm{SB}}=$ Coefficient of steam to biomass ratio term

$\mathrm{X}_{\mathrm{RT}}=$ Residence time, seconds

$\mathrm{B}_{\mathrm{RT}}=$ Coefficient of residence time term

$\mathrm{S}_{\mathrm{TC}}{ }^{2}=$ Gasification temperature squared term

$\mathrm{B}_{\mathrm{TC}}{ }^{2}=$ Gasification temperature squared coefficient

$\mathrm{S}_{\mathrm{SB}}^{2}=$ Steam to biomass ratio squared value

$\mathrm{B}_{\mathrm{SB}}^{2}=$ Steam to biomass ratio squared coefficient

$\mathrm{S}_{\mathrm{RT}}^{2}=$ Residence time squared value

$\mathrm{B}_{\mathrm{RT}}{ }^{2}=$ Residence time squared coefficient

$\mathrm{I}_{\mathrm{TC}: \mathrm{SB}}=$ Gasification temperature - steam to biomass ratio interaction value

$\mathrm{B}_{\mathrm{TC}: \mathrm{SB}}=$ Gasification temperature - steam to biomass ratio interaction coefficient

$\mathrm{I}_{\mathrm{TC}: \mathrm{RT}}=$ Gasification temperature - residence time interaction value

$\mathrm{B}_{\mathrm{TC}: \mathrm{RT}}=$ Gasification temperature - residence time interaction coefficient

$\mathrm{I}_{\mathrm{SB}: \mathrm{RT}}=$ Steam to biomass ratio - residence time interaction value

$\mathrm{B}_{\mathrm{SB}: \mathrm{RT}}=$ Steam to biomass ratio - residence time interaction coefficient

The linear terms for the ultimate analysis mass percents, proximate analysis mass percents, gasification temperature, steam to biomass ratio, and residence time are all calculated by simply multiplying the measured value for the input variable by its respective coefficient. The squared and interaction values, on the other hand, are calculated as follows: 
If $\mathrm{S}_{\mathrm{A}}{ }^{2}$ is the square value of input process variable $\mathrm{A}$, and $\mathrm{I}_{\mathrm{AB}}$ is the interaction value between input process variables $\mathrm{A}$ and $\mathrm{B}$, then:

$$
\begin{aligned}
& \mathrm{S}_{\mathrm{A}}^{2}=\left(\operatorname{Weight}_{\mathrm{A}} *\left(\mathrm{X}_{\mathrm{A}}-\text { Center }_{\mathrm{A}}\right)\right)^{2} \text { and } \\
& \mathrm{I}_{\mathrm{AB}}=\mathrm{Weight}_{\mathrm{A}} *\left(\mathrm{X}_{\mathrm{A}}-\text { Center }_{\mathrm{A}}\right) * \mathrm{Weight}_{\mathrm{B}} *\left(\mathrm{X}_{\mathrm{B}}-\text { Center }_{\mathrm{B}}\right)
\end{aligned}
$$

where Weight $\mathrm{i}_{\mathrm{i}}$ and Center $\mathrm{i}_{\mathrm{i}}$ are values generated by Unscrambler used to calculate the squared and interaction terms. For every output variable a unique set of B intercept, B coefficient, weight, and center values are generated by Unscrambler. $X_{A}$ and $X_{B}$ are the measured values of the process variables (residence time, thermal cracker temperature, and steam to biomass ratio). Appendix A presents the correlation values for equations 1, 2, and 3, as well as the $\mathrm{R}^{2}$ value of the correlation equation for each predicted variable.

A common method of measuring the accuracy of a correlation equation is to predict an output variable using measured conditions, and then plot the predicted values versus the measured values. An example of a predicted versus measured plot is provided in Figure 1. In Figure 1, the predicted hydrogen production rate is plotted versus the measured hydrogen production rate.

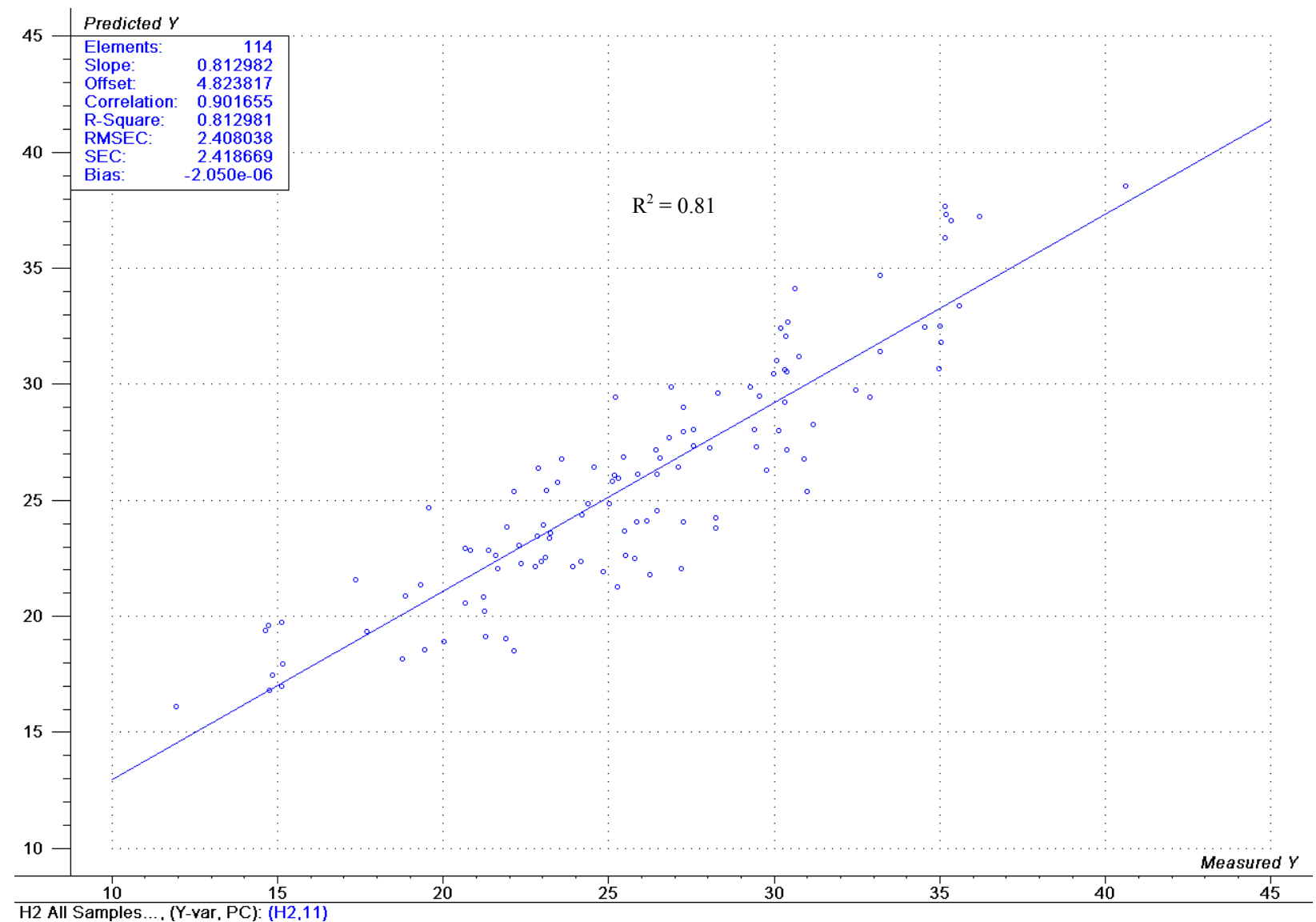

Figure 1. Sample Unscrambler regression plot, predicted versus measured $\mathrm{H}_{2}$ concentration (mol $\%)$ in the dry, scrubbed gas 


\section{Comparison of New and Old Correlations}

The new correlation equations predict most components better than the previous equations. In addition, several dry gas components and tar species not predicted with the old set of correlations can now be predicted. Table 1 below compares the performance of the new and old correlations using the $\mathrm{R}$-square value, $\mathrm{R}^{2}$, of the regression line drawn through the predicted versus measured plot.

The adjusted $\mathrm{R}$-square value, $\mathrm{R}_{\text {adj }}^{2}$, is also reported in Table 1 . The old correlation uses fewer terms and is based on a smaller data set than the new correlations. The adjusted $\mathrm{R}^{2}$ calculation considers the size of the data set as well as the number of terms used in the correlation equation. Thus, the original $\mathrm{R}^{2}$ values are "adjusted" to account for the size of the data set as well as the number of terms, which allows the two correlations to be compared more fairly. In this case, a comparison of the adjusted $\mathrm{R}^{2}$ values for the old and new correlations is consistent with a comparison of original $\mathrm{R}^{2}$ values; therefore the adjusted $\mathrm{R}^{2}$ results do not provide any new information but are included for the sake of completeness.

Table 1. $\mathbf{R}^{2}$ Values for New and Old Correlation Equations

\begin{tabular}{|c|c|c|c|c|}
\hline Component & New Correlation $\mathrm{R}^{2}$ & Old Correlation $\mathbf{R}^{2}$ & New Correlation $\mathbf{R}_{\text {adj }}^{2}$ & Old Correlation $\mathbf{R}_{\text {adj }}^{2}$ \\
\hline Hydrogen & 0.81 & 0.92 & 0.79 & 0.91 \\
\hline Carbon Monoxide & 0.64 & 0.40 & 0.60 & 0.36 \\
\hline Carbon Dioxide & 0.77 & 0.42 & 0.74 & 0.38 \\
\hline Methane & 0.81 & 0.70 & 0.79 & 0.68 \\
\hline Ethane & 0.71 & 0.85 & 0.68 & 0.84 \\
\hline Ethylene & 0.87 & 0.88 & 0.85 & 0.87 \\
\hline Acetylene & 0.94 & 0.72 & 0.93 & 0.70 \\
\hline Propane & 0.90 & & 0.89 & \\
\hline Propene & 0.92 & & 0.91 & \\
\hline 1-Butene & 0.83 & & 0.81 & \\
\hline 2-c-Butene & 0.73 & & 0.70 & \\
\hline Hydrogen Sulfide & 0.86 & & 0.84 & \\
\hline Benzene & 0.93 & & 0.92 & \\
\hline Toluene & 0.72 & & 0.67 & \\
\hline Phenol & 0.91 & & 0.90 & \\
\hline Cresols & 0.89 & & 0.87 & \\
\hline Naphthalene & 0.92 & & 0.91 & \\
\hline Phenanthrene & 0.85 & & 0.83 & \\
\hline Heavy Tar, MW > 180 & 0.68 & & 0.63 & \\
\hline Total Tar, MW > 78 & 0.82 & 0.89 & 0.79 & 0.88 \\
\hline Char & 0.78 & 0.66 & 0.75 & 0.64 \\
\hline Nitrogen Free Dry Gas Yield & 0.87 & 0.94 & 0.85 & 0.94 \\
\hline
\end{tabular}




\section{Results of Wood to Hydrogen Model using New Correlations}

\subsection{Overview of Model}

In the model, wood is gasified using a low-pressure indirectly-heated circulating fluidized bed gasifier. Indirect heat is supplied by adding hot olivine to the gasifier. After gasification, olivine and char are separated from the syngas using cyclones. The char, mixed with olivine, is then combusted to add heat to the olivine, which is then re-circulated back to the gasifier. Steam is also added to the gasifier as a fluidizing agent. The syngas exiting the gasifier then passes through a catalytic tar reformer where hydrocarbons and tars are cracked and reformed with water to increase $\mathrm{CO}$ and $\mathrm{H}_{2}$ yields. The syngas is then cleaned of $\mathrm{CO}_{2}$ and $\mathrm{H}_{2} \mathrm{~S}$. The cleaned syngas then passes through two shift reactors that increase the $\mathrm{H}_{2}$ to $\mathrm{CO}$ ratio. Pressure swing absorption (PSA) is then used to separate hydrogen from the syngas.

The feedstock used for the model is hybrid poplar wood chips delivered at $50 \mathrm{wt} \%$ moisture. The capacity of the model is 2,000 bone dry tonnes/day. The model requires a small amount of natural gas, although more will probably be necessary for startup. The majority of steam and electricity necessary to operate the envisioned facility is produced by combusting byproducts.

The 2005 Biomass to Hydrogen Design Report (Spath et al, 2005) presents a techno-economic analysis for two design cases: a current design case and a goal design case. The current design case assumes tar conversion rates verified experimentally with no regeneration of the tar reforming catalyst. The current design case also includes a steam-methane reformer, prior to the shift reactors, to convert methane and hydrocarbons to $\mathrm{CO}$ and $\mathrm{H}_{2}$. However, the goal design case assumes higher (goal) tar conversion, and includes a tar and methane reforming, catalyst regenerating reactor. As such, the goal design case does not include a steam-methane reformer because conversion of methane and hydrocarbons in the tar reformer is high enough that a steammethane reformer is not justified.

More detailed descriptions of the current and goal case designs are presented in the 2005 Biomass to Hydrogen Design Report (Spath et al. 2005). A block flow diagram of the goal case design is presented in Figure 2. 


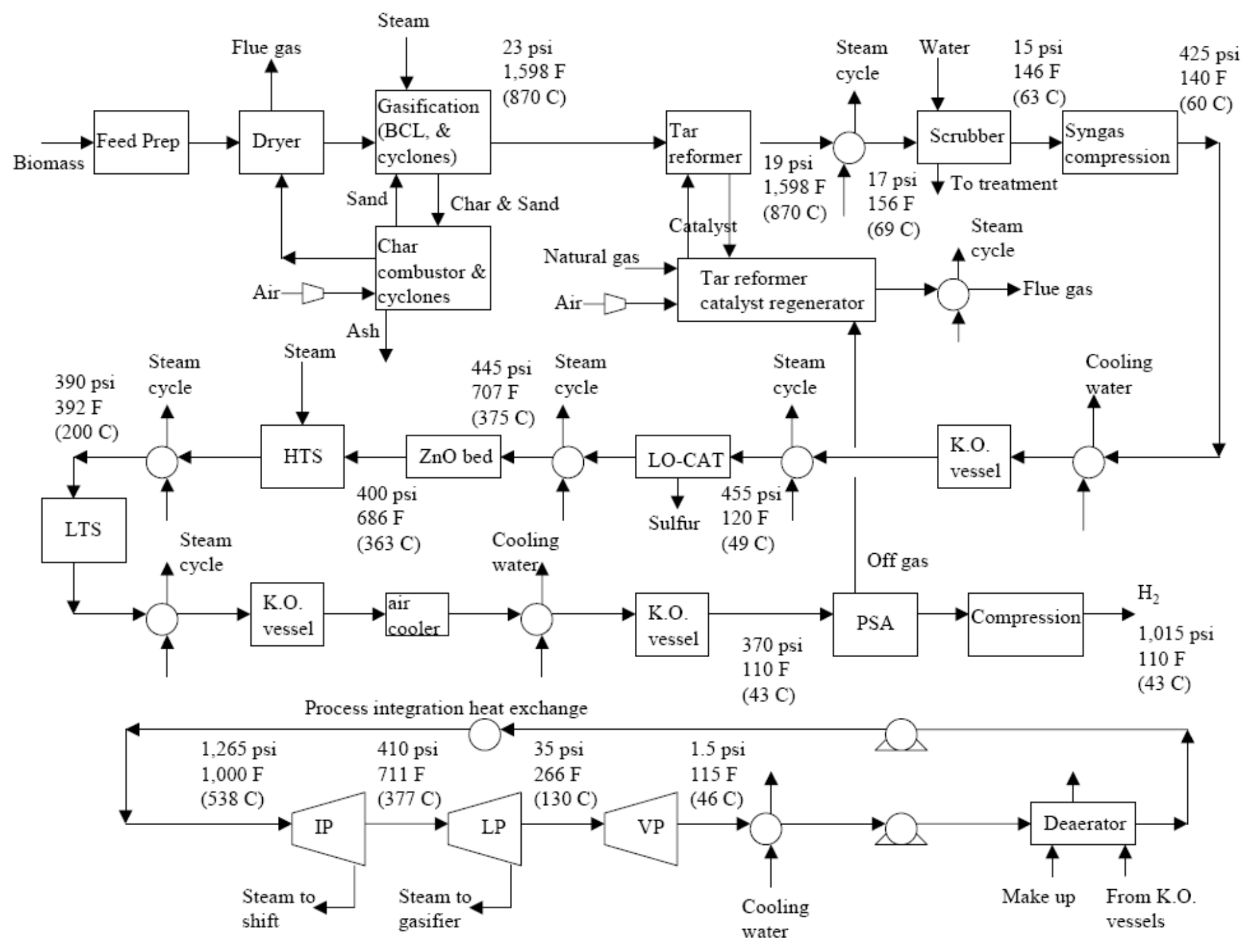

Figure 2. Block flow diagram of goal case design (Spath et al. 2005) 


\subsection{Results of Goal Case Design with New Correlations}

Table 2 compares the gasifier performance for the goal case design using the old and new correlations.

Table 2. Gasifier Operating Parameters, Yields, and Gas Compositions Using New and Old Correlation Equations

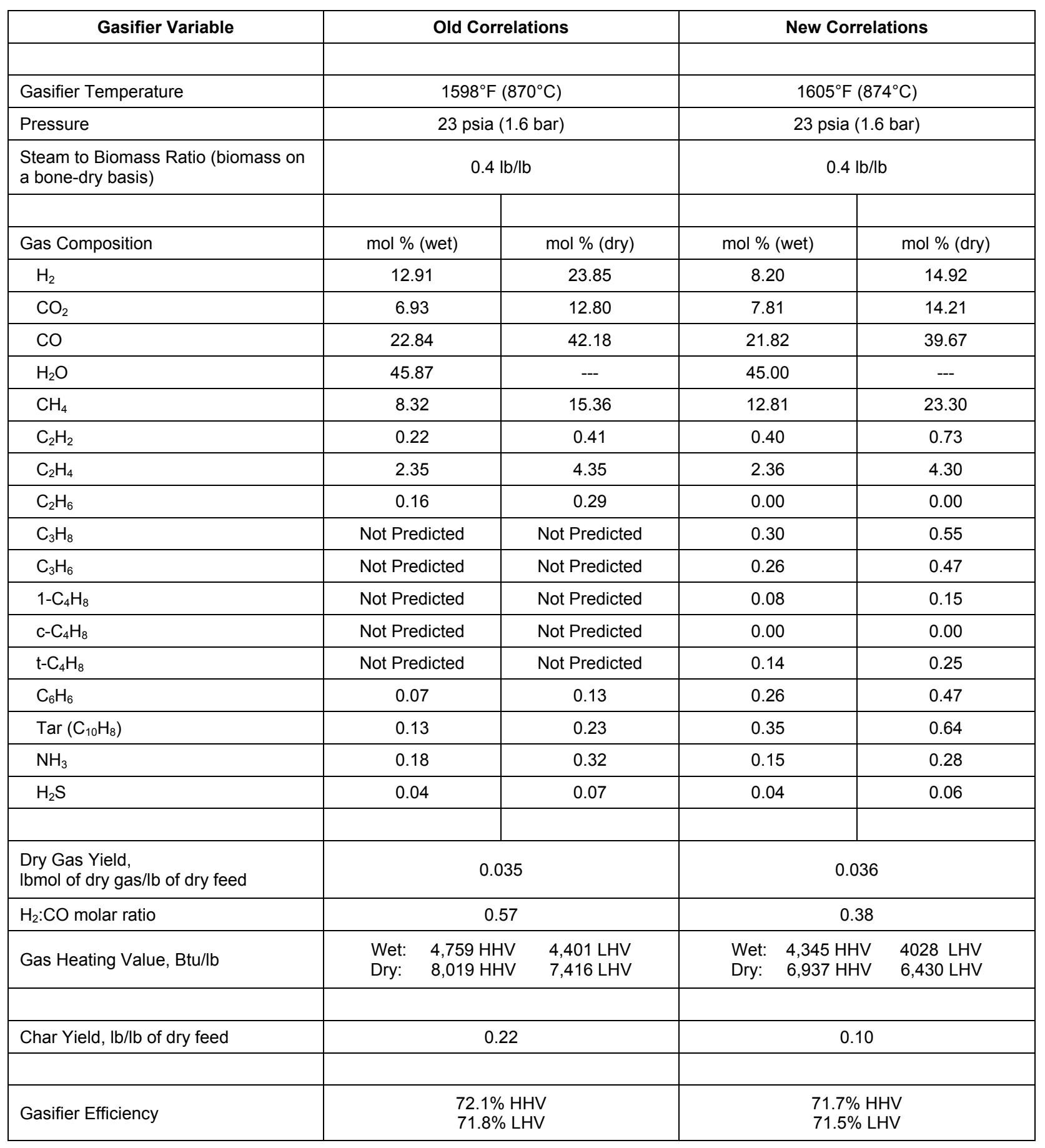


After replacing the old correlations with the new correlations, the most significant change to the gasifier product composition is the char yield. Using the old correlations, about $0.22 \mathrm{lb}$ of char is produced for every pound of moisture-free biomass fed to the gasifier. Using the new correlations, about $0.10 \mathrm{lb}$ of char is produced. Ten percent char yield is more consistent with literature values than $22 \%$ for the conditions modeled (gasification temperature, pressure, steamto-biomass ratio). Char is not a primary or secondary product of the biomass to hydrogen process, but because it is combusted to heat the olivine it does affect the heat balance of the indirect gasification system as well as the overall heat balance of the entire model. The amount of char produced according to the new correlations does not provide enough heat to maintain the gasifier above $1400^{\circ} \mathrm{F}$, therefore $23 \%$ of the raw syngas must be combusted with the char to provide the indirect heat necessary to maintain a gasification temperature close to $1600^{\circ} \mathrm{F}$. Also, flue gas from the char combustor is used to dry the incoming biomass from $50 \mathrm{wt} \%$ moisture to $12 \mathrm{wt} \%$ moisture. Less char requires less air for combustion, resulting in less flue gas available for drying. The amount of flue gas produced by the char combustor according to the new correlations does not provide enough heat to dry the incoming biomass to a moisture content of $12 \mathrm{wt} \%$. Diverting $23 \%$ of the raw syngas to the char combustor results in enough flue gas to dry the incoming biomass to $12 \mathrm{wt} \%$.

Less char is predicted using the new correlations because the new char correlation is based on char collected during the TCPDU experiments, whereas the old correlations are based on experiments that calculated the char yield using carbon balance equations. Char was not actually collected during the experiments that provided data for the old correlations.

The gasifier reaches an equilibrium temperature based on the amount of heat delivered indirectly from the char combustor. Applying the new correlations to the model resulted in an equilibrium gasification temperature of $1605^{\circ} \mathrm{F}\left(874^{\circ} \mathrm{C}\right)$, rather than $1598^{\circ} \mathrm{F}\left(870^{\circ} \mathrm{C}\right)$.

Compared to the old correlations, the raw syngas composition (including tars) predicted using the new correlations is significantly different for several components: more $\mathrm{CH}_{4}$ and tars are produced, although less $\mathrm{H}_{2}$ is produced. These changes may initially appear significant, but the differences in gas composition and dry gas yield exiting the gasifier are largely nullified by downstream operations. The additional $\mathrm{CH}_{4}$ and tars predicted by the new correlation suggest more hydrogen will be bound to carbon and not available as $\mathrm{H}_{2}$ product, however the reformer converts $80 \%$ of $\mathrm{CH}_{4}$ and $99.9 \%$ of tars to $\mathrm{CO}$ and $\mathrm{H}_{2}$. Also, the lower $\mathrm{H}_{2}$ to $\mathrm{CO}$ ratio predicted by the new correlations suggest that the final $\mathrm{H}_{2}$ product yield will decrease. However, the downstream shift reactors increase the ratio, making the ultimate effect on the final $\mathrm{H}_{2}$ product yield negligible.

The envisioned facility is designed to be a stand-alone plant requiring very little external power or fuel supplies. Most electricity and steam are generated on-site by combusting byproducts such as char and PSA off gas. Therefore, improvements in dry gas yield or product yield almost inevitably result in less byproducts to power the facility. Consequently, a portion of the intermediate streams must be diverted to generate the required steam and power. In this case, the raw syngas exiting the gasifier was diverted, although other streams such as the syngas leaving the tar cracker or the incoming biomass feed stream are also candidates to supplement steam and power generation. For this reason, the overall efficiency and economics for this stand-alone plant do not change significantly when the new correlations are applied. This may not be the case for 
all models. Table 3 compares the overall plant results for the old correlations versus new correlations.

Table 3. Overall Plant Performance Metrics for Old and New Gasifier Correlations

\begin{tabular}{|l|c|c|c|}
\hline & Old Correlations & New Correlations & $\%$ Change \\
\hline Hydrogen Production & $15,322 \mathrm{lb} / \mathrm{hr}(71.5 \mathrm{MMSCFD})$ & $15,728 \mathrm{lb} / \mathrm{hr}(73.4 \mathrm{MMSCFD})$ & $+2.6 \%$ \\
\hline Electricity Purchased from Grid & $10,285 \mathrm{~kW}(13,792 \mathrm{HP})$ & $4,477 \mathrm{~kW}(6,004 \mathrm{HP})$ & $-56.8 \%$ \\
\hline Natural Gas Use & $3739 \mathrm{lb} / \mathrm{hr}$ & $7198 \mathrm{lb} / \mathrm{hr}$ & $+92.5 \%$ \\
\hline Overall Plant Efficiency & $53.3 \% \mathrm{HHV}$ & $53.9 \% \mathrm{HHV}$ & $+1.1 \% \mathrm{HHV}$ \\
& $47.7 \% \mathrm{LHV}$ & $48.5 \% \mathrm{LHV}$ & $+1.7 \% \mathrm{LHV}$ \\
\hline
\end{tabular}

\section{Updated Economic Analysis using New Correlations}

The economic analysis consists of first estimating the capital and operating costs, then calculating a minimum hydrogen selling price using a discounted cash flow rate of return analysis. A brief explanation of the economic analysis is provided in this section. A more detailed explanation is provided in the 2005 Biomass to Hydrogen Technical Report (Spath et al. 2005). All capital and operating costs for this economic analysis are based on cost data from the same technical report.

\subsection{Capital Costs}

The purchased cost of most equipment came from literature sources and Questimate (AspenTech cost estimation software). The installed equipment costs were calculated by multiplying the purchased costs by installation cost factors in Peters and Timmerhaus (Peters and Timmerhaus 2003).

Indirect costs are non-process fixed capital investment costs, such as road and fence construction and legal fees. The indirect costs are calculated by multiplying the total purchased equipment costs by scaling factors in Peters and Timmerhaus (Peters and Timmerhaus 2003).

The sum of the total installed cost and the total indirect cost is the total project investment (TPI).

\subsection{Operating Costs}

For this economic analysis, both variable and fixed operating costs were considered. Variable operating costs are operating costs that can change when the process inputs or conditions change. Examples of variable operating costs are natural gas and boiler water chemicals. Variable operating costs are estimated on a per unit basis (per kg of feed, per scf of syngas, etc.), and then the total variable cost is calculated by multiplying per unit cost by the total number of units.

Fixed operating costs are costs such as employee salaries, overhead, and maintenance. These costs were assumed equal to the 2005 Biomass to Hydrogen Technical Report (Spath et al. 2005).

The sum of the variable operating costs and the fixed operating costs is the total operating cost (TOC). 


\subsection{Discounted Cash Flow Rate of Return Analysis (DCFROR)}

After the total capital cost and total operating cost have been estimated, a minimum hydrogen selling price (MHSP) can be calculated using a discounted cash flow rate of return analysis. Data from the Aspen Plus simulation are downloaded to a Microsoft Excel workbook that contains capital and operating cost data, as well as economic assumptions. The Excel goal seek function is then used to calculate a MHSP. Table 4 lists several economic assumptions used in the DCFROR analysis.

Table 4. Economic Assumptions Used in DCFROR Analysis

\begin{tabular}{|l|c|}
\multicolumn{1}{|c|}{ Assumption } & Value \\
\hline Internal rate of return (after-tax) & $10 \%$ \\
\hline Debt/equity & $0 \% / 100 \%$ \\
\hline Plant life & 20 years \\
\hline General plant depreciation & 200\% Double Declining Balance \\
\hline General plant recovery period & 7 years \\
\hline Steam plant depreciation & $150 \%$ DDB \\
\hline Steam plant recovery period & 20 years \\
\hline Construction period & 2.5 years $8 \%$ \\
$1^{\text {st }} 6$ months expenditures & $8 \%$ \\
Next 12 months expenditures & $60 \%$ \\
Last 12 months expenditures & $32 \%$ \\
\hline Start-up time & 6 months \\
Revenues & $50 \%$ \\
Variable costs & $75 \%$ \\
Fixed costs & an expense in the ${ }^{\text {st }}$ construction year) \\
\hline Working capital & $100 \%$ \\
\hline Land & $5 \%$ of Total Capital Investment \\
\hline
\end{tabular}

\subsection{New Correlations versus Old Correlations in 2002 Dollars}

The results of the model with both new and old correlations were used to calculate a MHSP using the DCFROR analysis spreadsheet. When the new correlations are used, the MHSP remains $\$ 1.24$ per kg in 2002 dollars. The new and old correlations were compared in 2002 dollars because the original economic analysis by Spath was done in 2002 dollars. While the final selling price remains unchanged, the operating costs, primarily natural gas and electricity purchased, are slightly different due to differences in intermediate stream flowrates and compositions. The results are presented in Tables 5 and 6. 
Table 5. DCFROR Summary Sheet for Old Correlations in 2002 Dollars

\section{Hydrogen Production Process Engineering Analysis}

Design Report: Goal Case with Old Correlations in 2002 Dollars

2000 Dry Metric Tonnes Biomass per Day

BCL Gasifier, Tar Reformer, Sulfur Removal, HTS \& LTS, PSA, Steam-Power Cycle All Values in $2002 \$$

Minimum Hydrogen Selling Price $(\$ / \mathrm{kg}) \$ 1.24$

$\$ 8.66$ (\$/GJ H2, HHV basis)

$\$ 10.34$ (\$/GJ H2, LHV basis)

Hydrogen Production at operating capacity (MM kg / year) 58.4

Hydrogen Yield (kg / Dry US Ton Feedstock) 75.7

Delivered Feedstock Cost \$/Dry US Ton $\$ 30$

Internal Rate of Return (After-Tax) 10\%

Equity Percent of Total Investment $100 \%$

70.6 (Million SCF / day)

2,116 (dry tons / day)

at operating capacity

\begin{tabular}{lr}
\multicolumn{2}{c}{ Capital Costs } \\
\hline Feed Handling \& Drying & $\$ 18,900,000$ \\
Gasification, Tar Reforming/Regeneration, \& Quench & $\$ 23,800,000$ \\
Compression \& Sulfur Removal & $\$ 16,100,000$ \\
Shift, and PSA & $\$ 16,500,000$ \\
Hydrogen Compression & $\$ 2,800,000$ \\
Steam System and Power Generation & $\$ 14,200,000$ \\
Cooling Water and Other Utilities & $\$ 3,400,000$ \\
\cline { 2 - 2 } Total Installed Equipment Cost & $\$ 95,700,000$ \\
& \\
Indirect Costs & $48,800,000$ \\
(\% of TPI) & $33.8 \%$ \\
Total Project Investment (TPI) & \\
& \\
& \\
Loan Rate & $\mathrm{N} / \mathrm{A}$ \\
Term (years) & 0.184 \\
Capital Charge Factor & \\
& \\
Maximum Yields (100\% of Theoretical) based on composition & 1100,000 \\
Theoretical Hydrogen Production (MM kg/yr) & 155.0 \\
Theoretical Yield (kg/dry ton) & $49 \%$ \\
Current Yield (Actual/Theoretical) & \\
Gasifier Efficiency - HHV & $70.8 \%$ \\
Gasifier Efficiency - LHV & $69.3 \%$ \\
Overall Plant Efficiency - HHV & $53.0 \%$ \\
Overall Plant Efficiency - LHV & $47.1 \%$ \\
&
\end{tabular}

\begin{tabular}{lr}
\multicolumn{2}{c}{ Operating Costs (cents/kg hydrogen) } \\
\hline Feedstock & 39.7 \\
Natural Gas & 5.9 \\
Catalysts & 0.7 \\
Olivine & 6.6 \\
Other Raw Materials & 0.9 \\
Waste Disposal & 1.2 \\
Electricity & 7.1 \\
Fixed Costs & 16.8 \\
Capital Depreciation & 12.3 \\
Average Income Tax & 9.8 \\
Average Return on Investment & 23.3
\end{tabular}

Average Return on Investment

\begin{tabular}{lr}
\multicolumn{2}{c}{ Operating Costs $(\$ / \mathrm{yr})$} \\
\hline Feedstock & $\$ 23,200,000$ \\
Natural Gas & $\$ 3,400,000$ \\
Catalysts & $\$ 400,000$ \\
Olivine & $\$ 3,800,000$ \\
Other Raw Matl. Costs & $\$ 500,000$ \\
Waste Disposal & $\$ 700,000$ \\
Electricity & $\$ 4,100,000$ \\
Fixed Costs & $\$ 9,800,000$ \\
Capital Depreciation & $\$ 7,200,000$ \\
Average Income Tax & $\$ 5,700,000$ \\
Average Return on Investment & $\$ 13,600,000$ \\
& \\
Total Plant Electricity Usage (KW) & 40259 \\
$\quad$ Electricity Produced Onsite (KW) & -29974 \\
$\quad$ Electricity Purchased from Grid (KW) & 10284 \\
Plant Electricity Use (KWh/kg H2) & 5.79 \\
Plant Steam Use (kg steam/kg H2) & $19.5^{\star}$
\end{tabular}




\section{Table 6. DCFROR Summary Sheet for New Correlations in 2002 Dollars}

\section{Hydrogen Production Process Engineering Analysis}

Design Report: Goal Case with New Correlations in 2002 Dollars

2000 Dry Metric Tonnes Biomass per Day

BCL Gasifier, Tar Reformer, Sulfur Removal, HTS \& LTS, PSA, Steam-Power Cycle All Values in $2002 \$$

Minimum Hydrogen Selling Price $(\$ / \mathrm{kg}) \$ 1.24$

$\$ 8.63$ (\$/GJ H2, HHV basis)

$\$ 10.30$ (\$/GJ H2, LHV basis)

Hydrogen Production at operating capacity (MM kg / year) 60.0

Hydrogen Yield (kg / Dry US Ton Feedstock) 77.7

Delivered Feedstock Cost \$/Dry US Ton $\$ 30$

Internal Rate of Return (After-Tax) 10\%

Equity Percent of Total Investment $100 \%$

72.5 (Million SCF / day)

2,116 (dry tons / day)

at operating capacity

\begin{tabular}{lr}
\multicolumn{2}{c}{ Capital Costs } \\
\hline Feed Handling \& Drying & $\$ 18,900,000$ \\
Gasification, Tar Reforming/Regeneration, \& Quench & $\$ 23,700,000$ \\
Compression \& Sulfur Removal & $\$ 14,500,000$ \\
Shift, and PSA & $\$ 16,700,000$ \\
Hydrogen Compression & $\$ 2,900,000$ \\
Steam System and Power Generation & $\$ 15,100,000$ \\
Cooling Water and Other Utilities & $\$ 3,500,000$ \\
\cline { 2 - 2 } Total Installed Equipment Cost & $\$ 95,300,000$ \\
& \\
Indirect Costs & $48,600,000$ \\
(\% of TPI) & $33.8 \%$ \\
& \\
Total Project Investment (TPI) & $\$ 143,800,000$ \\
& $\mathrm{~N} / \mathrm{A}$ \\
& $\mathrm{N} / \mathrm{A}$ \\
Loan Rate & 0.184 \\
Term (years) & \\
Capital Charge Factor & 119.7 \\
Maximum Yields (100\% of Theoretical) based on composition & 155.0 \\
Theoretical Hydrogen Production (MM kg/yr) & $50 \%$ \\
Theoretical Yield (kg/dry ton) & \\
Current Yield (Actual/Theoretical) & $70.8 \%$ \\
& $69.3 \%$ \\
Gasifier Efficiency - HHV & $53.0 \%$ \\
Gasifier Efficiency - LHV & $47.1 \%$ \\
Overall Plant Efficiency - HHV & \\
Overall Plant Efficiency - LHV & \\
&
\end{tabular}

\begin{tabular}{lr}
\multicolumn{2}{c}{ Operating Costs (cents/kg hydrogen) } \\
\hline Feedstock & 38.6 \\
Natural Gas & 11.0 \\
Catalysts & 0.6 \\
Olivine & 6.3 \\
Other Raw Materials & 0.9 \\
Waste Disposal & 1.1 \\
Electricity & 4.5 \\
Fixed Costs & 16.3 \\
Capital Depreciation & 12.0 \\
Average Income Tax & 9.6 \\
Average Return on Investment & 22.6
\end{tabular}

Average Return on Investment
Operating Costs (\$/yr)

\begin{tabular}{lr}
\multicolumn{2}{c}{ Operating Costs $(\$ / \mathrm{yr})$} \\
\hline Feedstock & $\$ 23,200,000$ \\
Natural Gas & $\$ 6,600,000$ \\
Catalysts & $\$ 400,000$ \\
Olivine & $\$ 3,800,000$ \\
Other Raw Matl. Costs & $\$ 500,000$ \\
Waste Disposal & $\$ 700,000$ \\
Electricity & $\$ 2,700,000$ \\
Fixed Costs & $\$ 9,800,000$ \\
Capital Depreciation & $\$ 7,200,000$ \\
Average Income Tax & $\$ 5,700,000$ \\
Average Return on Investment & $\$ 13,600,000$ \\
& \\
Total Plant Electricity Usage (KW) & 38952 \\
$\quad$ Electricity Produced Onsite (KW) & -32158 \\
$\quad$ Electricity Purchased from Grid (KW) & 6794 \\
Plant Electricity Use (KWh/kg H2) & 5.46 \\
Plant Steam Use (kg steam/kg H2) & $19.8^{\star}$
\end{tabular}




\section{Updated Economics}

\subsection{Economic Results Using 2005 Biomass Program Assumptions}

In 2005, the biomass program updated several assumptions to make the DCFROR analysis more current, such as increasing the feedstock cost from $\$ 30$ to $\$ 35$ per dry U.S. ton and using 2005 dollars. The results of the updated DCFROR analysis with 2005 assumptions are presented in Table 7.

Table 7. DCFROR Summary Sheet for New Correlations in 2005 Dollars

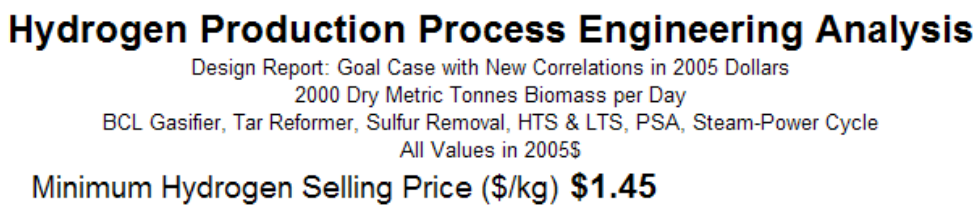

\$10.14 (\$/GJ H2, HHV basis)

$\$ 12.11$ (\$/GJ H2, LHV basis)

Hydrogen Production at operating capacity (MM kg / year) 60.0 Hydrogen Yield (kg / Dry US Ton Feedstock) 77.7 Delivered Feedstock Cost \$/Dry US Ton $\$ 35$ Internal Rate of Return (After-Tax) 10\%

Equity Percent of Total Investment $100 \%$
725 (Million SCF / day) 2,116 (dry tons / day) at operating capacity

\begin{tabular}{lr}
\multicolumn{2}{c}{ Capital Costs } \\
\hline Feed Handling \& Drying & $\$ 22,300,000$ \\
Gasification, Tar Reforming/Regeneration, \& Quench & $\$ 27,900,000$ \\
Compression \& Sulfur Removal & $\$ 17,100,000$ \\
Shift, and PSA & $\$ 19,700,000$ \\
Hydrogen Compression & $\$ 3,400,000$ \\
Steam System and Power Generation & $\$ 17,800,000$ \\
Cooling Water and Other Utilities & $\$ 4,100,000$ \\
\cline { 2 - 2 } Total Installed Equipment Cost & $\$ 112,300,000$ \\
& \\
Indirect Costs & $48,200,000$ \\
(\% of TPI) & $33.8 \%$ \\
Total Project Investment (TPI) & \\
& \\
& \\
Loan Rate & $\mathrm{N} / \mathrm{A}$ \\
Term (years) & $\mathrm{N} / \mathrm{A}$ \\
Capital Charge Factor & 0.187 \\
& \\
Maximum Yields (100\% of Theoretical) based on composition & \\
Theoretical Hydrogen Production (MM kg/yr) & 119.7 \\
Theoretical Yield (kg/dry ton) & 155.0 \\
Current Yield (Actual/Theoretical) & $50 \%$ \\
Gasifier Efficiency - HHV & \\
Gasifier Efficiency - LHV & $70.8 \%$ \\
Overall Plant Efficiency - HHV & $69.3 \%$ \\
Overall Plant Efficiency - LHV & $53.0 \%$ \\
& $47.1 \%$ \\
& \\
& \\
& \\
& \\
& \\
& \\
& \\
& \\
&
\end{tabular}

\begin{tabular}{|c|c|}
\hline \multicolumn{2}{|c|}{ Operating Costs (cents $/ \mathrm{kg}$ hydrogen) } \\
\hline Feedstock & $\overline{55.6}$ \\
\hline Natural Gas & 12.7 \\
\hline Catalysts & 0.6 \\
\hline Olivine & 7.0 \\
\hline Other Raw Materials & 1.1 \\
\hline Waste Disposal & 1.3 \\
\hline Electricity & 5.6 \\
\hline Fixed Costs & 16.7 \\
\hline Capital Depreciation & 11.8 \\
\hline Average Income Tax & 9.8 \\
\hline Average Return on Investment & 22.8 \\
\hline \multicolumn{2}{|c|}{ Operating Costs $(\$ / y r)$} \\
\hline Feedstock & $\$ 33,300,000$ \\
\hline Natural Gas & $\$ 7,600,000$ \\
\hline Catalysts & $\$ 400,000$ \\
\hline Olivine & $\$ 4,200,000$ \\
\hline Other Raw Matl. Costs & $\$ 700,000$ \\
\hline Waste Disposal & $\$ 800,000$ \\
\hline Electricity & $\$ 3,400,000$ \\
\hline Fixed Costs & $\$ 10,000,000$ \\
\hline Capital Depreciation & $\$ 7,100,000$ \\
\hline Average Income Tax & $\$ 5,900,000$ \\
\hline Average Return on Investment & $\$ 13,700,000$ \\
\hline Total Plant Electricity Usage (KW) & 38952 \\
\hline Electricity Produced Onsite (KW) & -32158 \\
\hline Electricity Purchased from Grid (KW) & 6794 \\
\hline Plant Electricity Use $\quad(\mathrm{KWh} / \mathrm{kg} \mathrm{H} 2)$ & 5.46 \\
\hline Plant Steam Use (kg steam $/ \mathrm{kg} \mathrm{H} 2)$ & $19.8^{\circ}$ \\
\hline
\end{tabular}

When 2005 economic assumptions are used, the MHSP increases from $\$ 1.24$ to $\$ 1.45$ per $\mathrm{kg}$. As expected, the new feedstock cost has a significant effect on the operating costs. According to sensitivity studies presented in the Biomass to Hydrogen Technical Report (Spath et al. 2005), the MHSP is more sensitive to feedstock cost than any other cost variable or process variable studied, therefore this is a reasonable and expected result.

Updating to 2005 dollars requires updating three cost indices, a plant cost index, an industrial inorganic chemical cost index, and a labor index. The plant cost index impacts capital costs, whereas the industrial inorganic chemical cost index and labor index impact operating costs. 
Between 2002 and 2005, all three indices increased, causing an increase in both capital and operating costs.

\subsection{Economic Results Using 2007 Biomass Program Assumptions}

To make the DCFROR analysis consistent with 2007 Biomass Program assumptions, the feedstock price was increased to $\$ 60$ per dry U.S. ton, and the cost indices were updated to 2007 dollars. The results of the DCFROR analysis using the new correlations and 2007 Biomass Program assumptions are presented in Table 8.

Table 8. DCFROR Summary Sheet for New Correlations in 2007 Dollars

\section{Hydrogen Production Process Engineering Analysis}

Design Report: Goal Case with New Correlations in 2007 Dollars 2000 Dry Metric Tonnes Biomass per Day

BCL Gasifier, Tar Reformer, Sulfur Removal, HTS \& LTS, PSA, Steam-Power Cycle All Values in $2007 \$$

$\$ 14.91$ (\$/GJ H2, HHV basis)

$\$ 17.81$ (\$/GJ H2, LHV basis)

72.5 (Million SCF / day)

2,116 (dry tons / day) at operating capacity Hydrogen Yield (kg / Dry US Ton Feedstock) 777 Delivered Feedstock Cost $\$$ /Dry US Ton $\$ 60$ Internal Rate of Return (After-Tax) 10\%

Equity Percent of Total Investment $100 \%$

\begin{tabular}{|c|c|}
\hline \multicolumn{2}{|l|}{ Capital Costs } \\
\hline Feed Handling \& Drying & $\$ 25,100,000$ \\
\hline Gasification, Tar Reforming/Regeneration, \& Quench & $\$ 31,400,000$ \\
\hline Compression \& Sulfur Removal & $\$ 19,200,000$ \\
\hline Shift, and PSA & $\$ 22,200,000$ \\
\hline Hydrogen Compression & $\$ 3,800,000$ \\
\hline Steam System and Power Generation & $\$ 20,100,000$ \\
\hline Cooling Water and Other Utilities & $\$ 4,700,000$ \\
\hline Total Installed Equipment Cost & $\$ 126,500,000$ \\
\hline Indirect Costs & $64,500,000$ \\
\hline$(\%$ of TPI) & 33.8 \\
\hline Total Project Investment (TPI) & $\$ 191,000,000$ \\
\hline Loan Rate & N \\
\hline Term (years) & N \\
\hline Capital Charge Factor & 0.1 \\
\hline Maximum Yields ( $100 \%$ of Theoretical) based on compos & \\
\hline Theoretical Hydrogen Production (MM kg/yr) & 119 \\
\hline Theoretical Yield (kg/dry ton) & 155 \\
\hline Current Yield (Actual/Theoretical) & $50^{\circ}$ \\
\hline Gasifier Efficiency - HHV & 70.8 \\
\hline Gasifier Efficiency - LHV & 69.3 \\
\hline Overall Plant Efficiency - HHV & 53.0 \\
\hline Overall Plant Efficiency - LHV & 47.1 \\
\hline
\end{tabular}

\begin{tabular}{lr}
\multicolumn{2}{c}{ Operating Costs (cents/kg hydrogen) } \\
\hline Feedstock & 103.4 \\
Natural Gas & 13.8 \\
Catalysts & 0.6 \\
Olivine & 7.6 \\
Other Raw Materials & 1.2 \\
Waste Disposal & 1.5 \\
Electricity & 6.1 \\
Fixed Costs & 20.1 \\
Capital Depreciation & 16.0 \\
Average Income Tax & 12.8 \\
Average Return on Investment & 30.5 \\
& \\
& \\
\hline Feedstock & \\
Natural Gas & \\
Catalysts & $\$ 62,000,000$ \\
Olivine & $\$ 8,300,000$ \\
Other Raw Matl. Costs & $\$ 400,000$ \\
Waste Disposal & $\$ 4,600,000$ \\
Electricity & $\$ 700,000$ \\
Fixed Costs & $\$ 900,000$ \\
Capital Depreciation & $\$ 3,600,000$ \\
Average Income Tax & $\$ 12,100,000$ \\
Average Return on Investment & $\$ 9,600,000$ \\
Total Plant Electricity Usage (KW) & $\$ 7,700,000$ \\
\multicolumn{1}{l}{ Electricity Produced Onsite (KW) } & $\$ 18,300,000$ \\
\multicolumn{1}{l}{ Electricity Purchased from Grid (KW) } & \\
Plant Electricity Use (KWh/kg H2) & 38952 \\
Plant Steam Use (kg steam/kg H2) & -32158 \\
& 6794 \\
& \\
& 5.46 \\
& 19.8
\end{tabular}

Between 2005 and 2007, the plant cost index and industrial inorganic chemical index both increased sharply, while the labor index increased less sharply. The final effect was an increase in both capital and operating costs, as expected, although the increase in feedstock cost from \$35 to $\$ 60$ per dry U.S. ton has the most significant impact. When 2005 assumptions are replaced with 2007 assumptions, the MHSP increases from \$1.45 to \$2.14 per kg. Most of the increase in MHSP can be attributed to increased feed cost. 


\subsection{Economic Results using H2A Analysis}

The Department of Energy (DOE) Hydrogen Program uses a separate economic evaluation spreadsheet, called H2A, available on the DOE H2A Analysis website. The Hydrogen Program H2A Cash Flow Analysis uses slightly different economic assumptions, such as plant capacity factor and life of project, than the Biomass Program DCFROR Analysis, therefore the results of the two analyses will vary slightly.

The H2A analysis resulted in a hydrogen cost of $\$ 1.56$ per $\mathrm{kg}$ in 2005 dollars using the new correlations versus $\$ 1.52$ using the old correlations. The major process and cost data used in the $\mathrm{H} 2 \mathrm{~A}$ analysis is summarized in Table 9.

Table 9. Summary of H2A Results

\begin{tabular}{|c|c|c|}
\hline & Old Correlations & New Correlations \\
\hline Biomass Usage, $\mathrm{kg}$ dry biomass per $\mathrm{kg} \mathrm{H}_{2}$ & 11.99 & 11.68 \\
\hline Electricity Usage, $\mathrm{kWh}$ per $\mathrm{kg} \mathrm{H}$ & 1.48 & 0.95 \\
\hline Natural Gas Usage, $\mathrm{Nm}^{3}$ per $\mathrm{kg} \mathrm{H}_{2}$ & 0.38 & 0.63 \\
\hline Cooling Water Usage, gal per kg $\mathrm{H}_{2}$ & 2.37 & 2.46 \\
\hline Process Water Usage, gal per $\mathrm{kg} \mathrm{H}_{2}$ & 1.60 & 2.23 \\
\hline Total Capital Costs, 2005 Dollars & $\$ 155.3$ million & $\$ 156.0$ million \\
\hline Annual Fixed Operating Costs, 2005 Dollars & $\$ 10.1$ million & $\$ 10.2$ million \\
\hline Annual Variable Operating Costs, 2005 Dollars & $\$ 43.7$ million & $\$ 47.5$ million \\
\hline Selling Price, 2005 Dollars per $\mathrm{kg} \mathrm{H}_{2}$ & $\$ 1.52$ & $\$ 1.56$ \\
\hline
\end{tabular}

\subsection{Summary of Economics}

The results of the DCFROR analyses are presented in Table 10.

Table 10. Summary of DCFROR Analyses

\begin{tabular}{|l|c|c|c|c|}
\hline & \multicolumn{2}{|c|}{ Hydrogen Program H2A Analysis } & \multicolumn{2}{c|}{ Biomass Program DCFROR Analysis } \\
\hline & Old Correlations & New Correlations & Old Correlations & New Correlations \\
\hline 2002 Dollars & & & $\$ 1.24$ & $\$ 1.24$ \\
\hline 2005 Dollars & $\$ 1.52$ & $\$ 1.56$ & $\$ 1.47$ & $\$ 1.45$ \\
\hline 2007 Dollars & & & & $\$ 2.14$ \\
\hline
\end{tabular}




\section{Conclusions}

The new correlations produce significantly different results for the gasifier, but only slightly different results for the overall process. Table 11 summarizes the differences.

Table 11. Summary of Conclusions

\begin{tabular}{|c|c|c|c|c|c|}
\hline Gasifier or Process Variable & \multicolumn{2}{|c|}{ Old Correlations } & \multicolumn{3}{|c|}{ New Correlations } \\
\hline $\begin{array}{l}\text { Gasifier Dry Gas Yield, } \\
\text { lbmol of dry gas/lb of dry feed }\end{array}$ & \multicolumn{2}{|c|}{0.035} & \multicolumn{3}{|c|}{0.036} \\
\hline Gasifier $\mathrm{H}_{2}: \mathrm{CO}$ molar ratio & \multicolumn{2}{|c|}{0.57} & \multicolumn{3}{|c|}{0.38} \\
\hline Gasifier Gas Heating Value Btu/lb & $\begin{array}{l}\text { 4,759 HHV } \\
8,019 \mathrm{HHV}\end{array}$ & $\begin{array}{l}\text { 4,401 LHV } \\
7,416 \text { LHV }\end{array}$ & $\begin{array}{l}\text { Wet: } \\
\text { Dry: }\end{array}$ & $\begin{array}{l}4,345 \mathrm{HHV} \\
6,937 \mathrm{HHV}\end{array}$ & $\begin{array}{l}4028 \text { LHV } \\
6,430 \text { LHV }\end{array}$ \\
\hline Gasifier Char Yield, lb/lb of dry feed & \multicolumn{2}{|c|}{0.22} & \multicolumn{3}{|c|}{0.10} \\
\hline Gasifier Efficiency & \multicolumn{2}{|c|}{$\begin{array}{l}72.1 \% \mathrm{HHV} \\
71.8 \% \mathrm{LHV}\end{array}$} & \multicolumn{3}{|c|}{$\begin{array}{l}71.7 \% \text { HHV } \\
71.5 \% \text { LHV }\end{array}$} \\
\hline Overall Process Hydrogen Production & \multicolumn{2}{|c|}{ 15,322 lb/hr (71.5 MMSCFD) } & \multicolumn{3}{|c|}{$15,728 \mathrm{lb} / \mathrm{hr}$ (73.4 MMSCFD) } \\
\hline Electricity Purchased from Grid & \multicolumn{2}{|c|}{$10,285 \mathrm{~kW}(13,792 \mathrm{HP})$} & \multicolumn{3}{|c|}{ 4,477 kW (6,004 HP) } \\
\hline Natural Gas Usage & \multicolumn{2}{|c|}{$3739 \mathrm{lb} / \mathrm{hr}$} & \multicolumn{3}{|c|}{$7198 \mathrm{lb} / \mathrm{hr}$} \\
\hline Overall Plant Efficiency & \multicolumn{2}{|c|}{$\begin{array}{l}53.3 \% \mathrm{HHV} \\
47.7 \% \mathrm{LHV}\end{array}$} & \multicolumn{3}{|c|}{$\begin{array}{l}53.9 \% \mathrm{HHV} \\
48.5 \% \mathrm{LHV}\end{array}$} \\
\hline MHSP, 2002 Dollars and Assumptions & \multicolumn{2}{|c|}{$\$ 1.24$} & \multicolumn{3}{|c|}{$\$ 1.24$} \\
\hline MHSP, 2007 Dollars and Assumptions & \multicolumn{2}{|c|}{$\mathrm{N} / \mathrm{A}$} & \multicolumn{3}{|c|}{$\$ 2.14$} \\
\hline
\end{tabular}

\section{References}

Bain, R. L. Material and Energy Balances for Methanol from Biomass Using Biomass Gasifiers. NREL/TP-510-17098. Golden, CO: National Renewable Energy Laboratory, 1992.

Hrdlicka, J.; Feik, C.; Carpenter, D.; Pomeroy, M. Parametric Gasification of Oak and Pine Feedstocks Using the TCPDU and Slipstream Water-Gas Shift Catalysis. NREL/TP-510-44557. Golden, CO: National Renewable Energy Laboratory, 2008.

Peters, M.S.; Timmerhaus, K.D. Plant Design and Economics for Chemical Engineers. $5^{\text {th }}$ edition. New York: McGraw-Hill, Inc., 2003.

Phillips, S.; Carpenter, D.; Gaston, K.; Deutch, S.; Feik, C.; Nimlos, M. Pilot Scale Parametric Gasification of Wood, Switchgrass and Wheat Straw to Develop Correlations for Input in Process Models. NREL Milestone Report 10298. Golden, CO: National Renewable Energy Laboratory, 2007.

Spath P.; Aden, A.; Eggeman, T.; Ringer, M.; Wallace, B.; Jechura, J. Biomass to Hydrogen Production Detailed Design and Economics Utilizing the Battelle Columbus Laboratory Indirectly-Heated Gasifier. NREL/TP-510-37408. Golden, CO: National Renewable Energy Laboratory, 2005. 


\section{Appendix A. Correlation Values for Equations 1, 2 and 3}

\begin{tabular}{|c|c|c|c|c|c|c|c|c|c|c|c|c|c|c|c|c|}
\hline \multicolumn{2}{|c|}{ Component Statistic } & C & $\mathrm{H}$ & $\mathrm{N}$ & $\mathrm{O}$ & S & TC & SB & RT & TC:SB & TC:RT & SB:RT & $\mathrm{TC}^{2}$ & $\mathrm{SB}^{2}$ & $\mathrm{RT}^{2}$ & $\mathrm{R}^{2}$ \\
\hline 1-Butene & B0 & 2.194 & & & & & & & & & & & & & & \\
\hline \multirow[t]{3}{*}{$\mathrm{C} 4 \mathrm{H} 8$} & B & 0.004 & 0.016 & -0.036 & -0.015 & 0.956 & -0.002 & -0.232 & 0.147 & 0.022 & -0.013 & 0.022 & -0.048 & -0.024 & 0.005 & 0.880 \\
\hline & Center & & & & & & 750.000 & 0.630 & 1.488 & & & & & & & \\
\hline & Weight & & & & & & 0.010 & 3.614 & 4.610 & & & & & & & \\
\hline 2-c-Butene & B0 & 0.250 & & & & & & & & & & & & & & \\
\hline \multirow[t]{3}{*}{$\mathrm{C} 4 \mathrm{H} 8$} & B & 0.000 & 0.013 & 0.065 & -0.005 & -0.740 & 0.000 & 0.000 & -0.004 & 0.003 & -0.002 & -0.002 & 0.015 & 0.001 & 0.002 & 0.712 \\
\hline & Center & & & & & & 745.944 & 0.632 & 1.494 & & & & & & & \\
\hline & Weight & & & & & & 0.010 & 3.577 & 4.391 & & & & & & & \\
\hline 2-t-Butene & B0 & 0.354 & & & & & & & & & & & & & & \\
\hline \multirow[t]{3}{*}{$\mathrm{C} 4 \mathrm{H} 8$} & B & -0.002 & -0.036 & -0.075 & 0.007 & 1.296 & 0.000 & -0.033 & -0.014 & 0.005 & 0.000 & 0.002 & 0.022 & -0.006 & 0.006 & 0.713 \\
\hline & Center & & & & & & 748.861 & 0.618 & 1.489 & & & & & & & \\
\hline & Weight & & & & & & 0.009 & 3.658 & 4.308 & & & & & & & \\
\hline Carbon Dioxide & BO & 38.897 & & & & & & & & & & & & & & \\
\hline \multirow[t]{3}{*}{$\mathrm{CO} 2$} & B & 0.077 & 1.525 & 5.268 & -0.416 & -73.339 & -0.024 & -2.212 & 5.363 & 0.529 & -0.563 & 0.023 & 0.961 & 0.198 & -0.218 & 0.812 \\
\hline & Center & & & & & & 745.989 & 0.636 & 1.498 & & & & & & & \\
\hline & Weight & & & & & & 0.010 & 3.562 & 4.362 & & & & & & & \\
\hline Carbon Monoxide & B0 & 18.479 & & & & & & & & & & & & & & \\
\hline \multirow[t]{3}{*}{$\mathrm{CO}$} & B & -0.091 & -2.750 & -11.893 & 0.724 & 160.964 & 0.002 & -4.578 & -0.022 & 0.063 & 0.417 & 0.297 & -0.258 & 0.592 & -0.052 & 0.689 \\
\hline & Center & & & & & & 745.989 & 0.636 & 1.498 & & & & & & & \\
\hline & Weight & & & & & & 0.010 & 3.562 & 4.362 & & & & & & & \\
\hline Ethane & B0 & 0.293 & & & & & & & & & & & & & & \\
\hline \multirow[t]{3}{*}{$\mathrm{C} 2 \mathrm{H} 6$} & B & -0.001 & 0.002 & 0.102 & -0.003 & -0.991 & 0.000 & -0.027 & 0.076 & 0.011 & -0.015 & -0.003 & 0.006 & 0.000 & -0.002 & 0.716 \\
\hline & Center & & & & & & 748.607 & 0.628 & 1.488 & & & & & & & \\
\hline & Weight & & & & & & 0.010 & 3.592 & 4.514 & & & & & & & \\
\hline Ethene & B0 & -2.721 & & & & & & & & & & & & & & \\
\hline \multirow[t]{3}{*}{$\mathrm{C} 2 \mathrm{H} 4$, Ethylene } & B & -0.016 & -0.303 & -0.585 & 0.027 & 12.660 & 0.010 & -0.411 & -0.043 & -0.217 & 0.180 & 0.106 & -0.179 & 0.050 & -0.074 & 0.958 \\
\hline & Center & & & & & & 745.989 & 0.636 & 1.498 & & & & & & & \\
\hline & Weight & & & & & & 0.010 & 3.562 & 4.362 & & & & & & & \\
\hline Ethyne & Bo & 7.390 & & & & & & & & & & & & & & \\
\hline \multirow[t]{3}{*}{$\mathrm{C} 2 \mathrm{H} 2$, Acetylene } & B & -0.003 & -0.037 & 0.057 & -0.005 & 0.572 & -0.007 & -0.587 & 0.426 & 0.099 & -0.046 & 0.032 & -0.240 & -0.002 & 0.018 & 0.964 \\
\hline & Center & & & & & & 745.989 & 0.636 & 1.498 & & & & & & & \\
\hline & Weight & & & & & & 0.010 & 3.562 & 4.362 & & & & & & & \\
\hline Helium & B0 & 3.892 & & & & & & & & & & & & & & \\
\hline \multirow[t]{3}{*}{$\mathrm{He}$} & B & 0.001 & -0.059 & 0.025 & -0.041 & 3.704 & -0.002 & 0.452 & 0.348 & 0.050 & -0.073 & -0.068 & 0.084 & -0.157 & 0.038 & 0.846 \\
\hline & Center & & & & & & 745.989 & 0.636 & 1.498 & & & & & & & \\
\hline & Weight & & & & & & 0.010 & 3.562 & 4.362 & & & & & & & \\
\hline
\end{tabular}




\begin{tabular}{|c|c|c|c|c|c|c|c|c|c|c|c|c|c|c|c|c|}
\hline \multicolumn{2}{|c|}{ Component Statistic } & C & $\mathrm{H}$ & $\mathrm{N}$ & $\mathrm{O}$ & $\mathrm{S}$ & $\mathrm{TC}$ & SB & RT & $\mathrm{B}_{\mathrm{TC}: \mathrm{SB}}$ & $\mathrm{B}_{\mathrm{TC}: \mathrm{RT}}$ & $\mathrm{B}_{\mathrm{SB}: \mathrm{RT}}$ & $\mathrm{B}_{\mathrm{TC}}{ }^{2}$ & $\mathrm{~B}_{\mathrm{SB}}^{2}$ & $\mathrm{~B}_{\mathrm{RT}}^{2}$ & $\mathrm{R}^{2}$ \\
\hline Hydrogen & Bo & 47.139 & & & & & & & & & & & & & & \\
\hline \multirow[t]{3}{*}{$\mathrm{H} 2$} & B & -0.030 & 1.559 & 10.667 & -0.352 & -139.271 & 0.005 & 20.304 & -19.415 & -1.294 & 0.719 & 1.057 & 0.206 & -0.238 & -1.311 & 0.780 \\
\hline & Center & & & & & & 745.989 & 0.636 & 1.498 & & & & & & & \\
\hline & Weight & & & & & & 0.010 & 3.562 & 4.362 & & & & & & & \\
\hline Methane & B0 & 0.087 & & & & & & & & & & & & & & \\
\hline \multirow[t]{3}{*}{$\mathrm{CH} 4$} & B & 0.043 & 0.030 & -2.272 & 0.011 & 24.372 & 0.012 & -4.429 & 3.565 & -0.374 & 0.440 & 0.654 & -0.093 & 0.252 & -0.346 & 0.846 \\
\hline & Center & & & & & & 745.989 & 0.636 & 1.498 & & & & & & & \\
\hline & Weight & & & & & & 0.010 & 3.562 & 4.362 & & & & & & & \\
\hline Propane & BO & -1.671 & & & & & & & & & & & & & & \\
\hline \multirow[t]{3}{*}{$\mathrm{C} 3 \mathrm{H} 8$} & B & 0.001 & -0.018 & -0.126 & 0.002 & 1.784 & 0.002 & 0.018 & -0.005 & -0.029 & 0.013 & 0.008 & 0.116 & 0.012 & -0.016 & 0.901 \\
\hline & Center & & & & & & 745.989 & 0.636 & 1.498 & & & & & & & \\
\hline & Weight & & & & & & 0.010 & 3.562 & 4.362 & & & & & & & \\
\hline Propene & BO & 4.045 & & & & & & & & & & & & & & \\
\hline \multirow[t]{3}{*}{$\mathrm{C} 3 \mathrm{H} 6$} & B & -0.002 & -0.047 & -0.116 & 0.002 & 2.400 & -0.004 & -0.364 & 0.247 & 0.054 & -0.014 & 0.035 & -0.150 & -0.002 & 0.008 & 0.954 \\
\hline & Center & & & & & & 745.989 & 0.636 & 1.498 & & & & & & & \\
\hline & Weight & & & & & & 0.010 & 3.562 & 4.362 & & & & & & & \\
\hline Carbonyl Sulfide & B0 & 2.784 & & & & & & & & & & & & & & \\
\hline \multirow[t]{3}{*}{$\cos$} & $B$ & 0.000 & -0.026 & -0.005 & -0.013 & 1.522 & -0.001 & -0.158 & -0.863 & -0.003 & -0.019 & 0.042 & -0.151 & 0.120 & 0.118 & 0.497 \\
\hline & Center & & & & & & 750.424 & 0.588 & 1.468 & & & & & & & \\
\hline & Weight & & & & & & 0.010 & 3.688 & 4.712 & & & & & & & \\
\hline Hydrogen Sulfide & B0 & 6.159 & & & & & & & & & & & & & & \\
\hline \multirow[t]{3}{*}{$\mathrm{H} 2 \mathrm{~S}$} & B & -0.036 & -0.892 & 0.702 & -0.294 & 34.016 & 0.019 & 4.599 & -4.983 & 0.091 & 0.529 & -0.254 & 0.424 & -0.040 & 0.443 & 0.850 \\
\hline & Center & & & & & & 742.692 & 0.618 & 1.472 & & & & & & & \\
\hline & Weight & & & & & & 0.010 & 3.633 & 4.372 & & & & & & & \\
\hline benzene & BO & & & & & & & & & & & & & & & \\
\hline \multirow[t]{3}{*}{$\mathrm{C} 6 \mathrm{H} 6$} & B & $-6.09 \mathrm{E}-05$ & $-3.60 \mathrm{E}-04$ & $1.08 \mathrm{E}-03$ & $1.03 \mathrm{E}-04$ & $-4.52 \mathrm{E}-03$ & $6.22 \mathrm{E}-05$ & $4.34 \mathrm{E}-03$ & $-1.62 \mathrm{E}-03$ & $-3.77 \mathrm{E}-04$ & $-4.56 \mathrm{E}-05$ & $-6.14 \mathrm{E}-04$ & $2.33 \mathrm{E}-03$ & $3.03 \mathrm{E}-04$ & $-4.59 \mathrm{E}-04$ & 0.971 \\
\hline & Center & & & & & & 748.214 & 0.636 & 1.487 & & & & & & & \\
\hline & Weight & & & & & & 0.010 & 3.545 & 4.257 & & & & & & & \\
\hline toluene & B0 & $1.60 \mathrm{E}-03$ & & & & & & & & & & & & & & \\
\hline \multirow[t]{3}{*}{$\mathrm{C} 7 \mathrm{H} 8$} & B & $-3.13 E-05$ & $-2.51 \mathrm{E}-04$ & $5.60 \mathrm{E}-04$ & $2.22 \mathrm{E}-05$ & $8.76 \mathrm{E}-04$ & $7.08 \mathrm{E}-06$ & $1.38 \mathrm{E}-03$ & $-4.72 \mathrm{E}-04$ & $-1.15 \mathrm{E}-04$ & $5.59 \mathrm{E}-06$ & $-2.41 \mathrm{E}-04$ & $-3.84 \mathrm{E}-04$ & $7.32 \mathrm{E}-05$ & $-7.27 \mathrm{E}-05$ & 0.833 \\
\hline & Center & & & & & & 755.682 & 0.642 & 1.497 & & & & & & & \\
\hline & Weight & & & & & & 0.010 & 3.551 & 4.569 & & & & & & & \\
\hline phenol & B0 & $1.96 \mathrm{E}-02$ & & & & & & & & & & & & & & \\
\hline \multirow[t]{3}{*}{$\mathrm{C} 6 \mathrm{H} 6 \mathrm{O}$} & B & $-1.12 \mathrm{E}-05$ & $-1.59 \mathrm{E}-04$ & $2.08 \mathrm{E}-04$ & $-2.55 \mathrm{E}-05$ & $3.97 \mathrm{E}-03$ & $-1.65 \mathrm{E}-05$ & $-6.91 \mathrm{E}-05$ & $8.21 \mathrm{E}-04$ & $-5.77 \mathrm{E}-06$ & $-1.17 \mathrm{E}-04$ & 4.36E-06 & $-1.33 E-03$ & $-8.73 E-05$ & $5.64 \mathrm{E}-05$ & 0.932 \\
\hline & Center & & & & & & 748.214 & 0.636 & 1.487 & & & & & & & \\
\hline & Weight & & & & & & 0.010 & 3.545 & 4.257 & & & & & & & \\
\hline
\end{tabular}




\begin{tabular}{|c|c|c|c|c|c|c|c|c|c|c|c|c|c|c|c|c|}
\hline \multicolumn{2}{|c|}{ Component Statistic } & C & $\mathrm{H}$ & $\mathrm{N}$ & $\mathrm{O}$ & S & TC & SB & RT & $\mathrm{B}_{\mathrm{TC}: \mathrm{SB}}$ & $\mathrm{B}_{\mathrm{TC}: \mathrm{RT}}$ & $\mathrm{B}_{\mathrm{SB}: \mathrm{RT}}$ & $\mathrm{B}_{\mathrm{TC}}{ }^{2}$ & $\mathrm{~B}_{\mathrm{SB}}{ }^{2}$ & $\mathrm{~B}_{\mathrm{RT}}{ }^{2}$ & $\mathrm{R}^{2}$ \\
\hline cresols & B0 & $1.84 \mathrm{E}-02$ & & & & & & & & & & & & & & \\
\hline \multirow[t]{3}{*}{$\mathrm{C} 7 \mathrm{H} 8 \mathrm{O}$} & B & $-6.76 E-06$ & $-1.32 \mathrm{E}-05$ & $1.17 \mathrm{E}-04$ & $2.41 \mathrm{E}-05$ & $-1.88 \mathrm{E}-03$ & $-1.93 \mathrm{E}-05$ & $-1.00 E-03$ & $2.68 \mathrm{E}-04$ & $-7.04 \mathrm{E}-06$ & $-1.02 \mathrm{E}-04$ & $1.49 \mathrm{E}-04$ & $-1.02 \mathrm{E}-03$ & $-1.97 \mathrm{E}-04$ & $1.70 \mathrm{E}-04$ & 0.942 \\
\hline & Center & & & & & & 748.214 & 0.636 & 1.487 & & & & & & & \\
\hline & Weight & & & & & & 0.010 & 3.545 & 4.257 & & & & & & & \\
\hline naphthalene & B0 & $-1.33 E-02$ & & & & & & & & & & & & & & \\
\hline \multirow[t]{3}{*}{$\mathrm{C} 10 \mathrm{H} 8$} & B & $-2.72 \mathrm{E}-05$ & $-2.04 \mathrm{E}-04$ & $4.85 \mathrm{E}-04$ & $2.40 \mathrm{E}-05$ & $2.91 \mathrm{E}-04$ & $2.24 \mathrm{E}-05$ & $9.26 \mathrm{E}-04$ & $-4.87 \mathrm{E}-04$ & $-1.85 \mathrm{E}-04$ & $3.32 \mathrm{E}-05$ & $-7.65 \mathrm{E}-05$ & $1.18 \mathrm{E}-03$ & $1.20 \mathrm{E}-04$ & $-1.29 \mathrm{E}-04$ & 0.978 \\
\hline & Center & & & & & & 746.377 & 0.631 & 1.482 & & & & & & & \\
\hline & Weight & & & & & & 0.010 & 3.563 & 4.300 & & & & & & & \\
\hline "other tar" & B0 & $3.81 \mathrm{E}-02$ & & & & & & & & & & & & & & \\
\hline \multirow{3}{*}{$\begin{array}{l}\text { Sum of toluene } \\
\text { through } \\
\text { phenanthrene }\end{array}$} & B & $-6.12 E-05$ & $-4.77 \mathrm{E}-04$ & $1.10 \mathrm{E}-03$ & 4.73E-05 & $1.55 \mathrm{E}-03$ & $-3.26 \mathrm{E}-05$ & $-3.14 \mathrm{E}-04$ & $1.53 \mathrm{E}-03$ & $3.23 \mathrm{E}-04$ & $-2.66 \mathrm{E}-04$ & $-2.83 \mathrm{E}-04$ & $8.53 \mathrm{E}-04$ & $-2.72 \mathrm{E}-04$ & $9.14 \mathrm{E}-05$ & 0.939 \\
\hline & Center & & & & & & 750.368 & 0.629 & 1.482 & & & & & & & \\
\hline & Weight & & & & & & 0.010 & 3.541 & 4.321 & & & & & & & \\
\hline phenanthrene & B0 & $-4.60 \mathrm{E}-03$ & & & & & & & & & & & & & & \\
\hline \multirow[t]{3}{*}{$\mathrm{C} 14 \mathrm{H} 10$} & B & $-7.58 \mathrm{E}-06$ & $-5.88 \mathrm{E}-05$ & $1.36 \mathrm{E}-04$ & $5.98 \mathrm{E}-06$ & $1.55 \mathrm{E}-04$ & $7.46 \mathrm{E}-06$ & $1.87 \mathrm{E}-04$ & $-1.54 \mathrm{E}-04$ & $-6.12 \mathrm{E}-05$ & $1.41 \mathrm{E}-05$ & $-6.67 E-06$ & $4.93 \mathrm{E}-04$ & 3.02E-05 & $-4.06 \mathrm{E}-05$ & 0.976 \\
\hline & Center & & & & & & 744.485 & 0.625 & 1.484 & & & & & & & \\
\hline & Weight & & & & & & 0.010 & 3.583 & 4.281 & & & & & & & \\
\hline "heavy tar" & Bo & $6.10 \mathrm{E}-03$ & & & & & & & & & & & & & & \\
\hline Sum of everything & B & $3.34 \mathrm{E}-05$ & $2.51 \mathrm{E}-04$ & $-5.97 \mathrm{E}-04$ & $-2.64 \mathrm{E}-05$ & $-4.95 \mathrm{E}-04$ & $2.27 \mathrm{E}-06$ & $-1.20 \mathrm{E}-03$ & $1.66 \mathrm{E}-03$ & $-4.64 \mathrm{E}-04$ & $3.82 \mathrm{E}-04$ & $-1.02 \mathrm{E}-04$ & $1.30 \mathrm{E}-03$ & $-2.39 \mathrm{E}-04$ & $-1.47 E-04$ & 0.549 \\
\hline \multirow[t]{2}{*}{ With MW > 180} & Center & & & & & & 745.833 & 0.618 & 1.470 & & & & & & & \\
\hline & Weight & & & & & & 0.010 & 3.584 & 4.460 & & & & & & & \\
\hline Total $(>78)$ & B0 & $6.53 \mathrm{E}-02$ & & & & & & & & & & & & & & \\
\hline Sum of everything & B & $-1.07 E-04$ & $-8.92 \mathrm{E}-04$ & $1.92 \mathrm{E}-03$ & $5.50 \mathrm{E}-05$ & $5.46 \mathrm{E}-03$ & $-2.87 \mathrm{E}-05$ & $3.06 \mathrm{E}-04$ & $2.58 \mathrm{E}-03$ & $-2.01 \mathrm{E}-04$ & $-2.72 \mathrm{E}-04$ & $-5.94 \mathrm{E}-04$ & $1.01 \mathrm{E}-03$ & $-4.72 E-04$ & $-9.48 \mathrm{E}-05$ & 0.767 \\
\hline \multirow[t]{2}{*}{ except benzene } & Center & & & & & & 746.591 & 0.618 & 1.479 & & & & & & & \\
\hline & Weight & & & & & & 0.010 & 3.584 & 4.350 & & & & & & & \\
\hline \multirow[t]{4}{*}{ Char } & B0 & 4.47E-01 & & & & & & & & & & & & & & \\
\hline & $B$ & 7.01E-04 & $-8.88 \mathrm{E}-03$ & $-1.11 E-02$ & $-7.38 \mathrm{E}-03$ & $7.23 \mathrm{E}-01$ & $-5.78 \mathrm{E}-05$ & $-1.22 \mathrm{E}-02$ & 2.18E-02 & $-2.84 \mathrm{E}-03$ & $-3.74 \mathrm{E}-03$ & $-2.84 \mathrm{E}-03$ & $-5.23 \mathrm{E}-04$ & $-1.12 \mathrm{E}-03$ & $-3.63 E-03$ & 0.740 \\
\hline & Center & & & & & & 748.214 & 0.636 & 1.487 & & & & & & & \\
\hline & Weight & & & & & & 0.010 & 3.545 & 4.257 & & & & & & & \\
\hline Nitrogen Free & B0 & 52.870 & & & & & & & & & & & & & & \\
\hline Outlet Dry Gas & B & 0.030 & 0.483 & -0.542 & 0.104 & -12.498 & 0.006 & 5.017 & -30.121 & 0.012 & -0.163 & -1.432 & 0.232 & -2.177 & 2.235 & 0.981 \\
\hline \multirow[t]{2}{*}{ Flow Rate } & Center & & & & & & 744.080 & 0.619 & 1.486 & & & & & & & \\
\hline & Weight & & & & & & 0.010 & 3.627 & 4.398 & & & & & & & \\
\hline
\end{tabular}




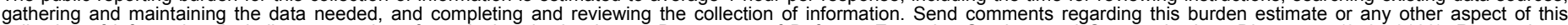

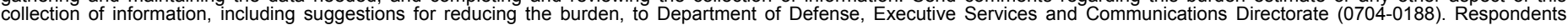

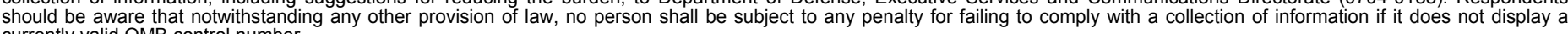

PLEASE DO NOT RETURN YOUR FORM TO THE ABOVE ORGANIZATION.

\section{REPORT DATE (DD-MM-YYYY) May 2009}

4. TITLE AND SUBTITLE

Hydrogen Production from Biomass via Indirect Gasification: The Impact of NREL Process Development Unit Gasifier Correlations
3. DATES COVERED (From - To)

5a. CONTRACT NUMBER

DE-AC36-08-GO28308

5b. GRANT NUMBER

5c. PROGRAM ELEMENT NUMBER

5d. PROJECT NUMBER

NREL/TP-510-44868

5e. TASK NUMBER

$\mathrm{H} 271.3 \mathrm{~B} 13$

5f. WORK UNIT NUMBER
7. PERFORMING ORGANIZATION NAME(S) AND ADDRESS(ES)

National Renewable Energy Laboratory

1617 Cole Blvd.

Golden, CO 80401-3393
8. PERFORMING ORGANIZATION REPORT NUMBER

NREL/TP-510-44868

9. SPONSORING/MONITORING AGENCY NAME(S) AND ADDRESS(ES)

10. SPONSOR/MONITOR'S ACRONYM(S) NREL

11. SPONSORING/MONITORING AGENCY REPORT NUMBER

12. DISTRIBUTION AVAILABILITY STATEMENT

National Technical Information Service

U.S. Department of Commerce

5285 Port Royal Road

Springfield, VA 22161

\section{SUPPLEMENTARY NOTES}

\section{ABSTRACT (Maximum 200 Words)}

NREL developed a new set of empirical gasifier correlations using data collected from the Thermochemical Process Development Unit. The new correlations replaced the old correlations in the Aspen Plus model presented in the Biomass to Hydrogen Design Report (Spath et al. 2005). The new correlations predict a slightly different dry gas composition, although the most significant difference is less char. The new correlations predict $0.10 \mathrm{lb}$ of char per $\mathrm{lb}$ of dry feed, whereas the old correlations predict $0.22 \mathrm{lb}$ of char; consequently, a portion of the raw syngas must be diverted to the char combustor to provide the heat necessary for gasification and drying the incoming biomass. The model predicts $2.6 \%$ more final hydrogen product when the new gasifier correlations are used. The new correlations also predict a minimum hydrogen selling price of \$1.24 per kg (2002 dollars), which equal to the \$1.24 per kg predicted by the old correlations. Using 2007 Biomass Program economic assumptions, the new correlations predict a minimum hydrogen selling price of $\$ 2.14$ per $\mathrm{kg}$ (2007 dollars).

\section{SUBJECT TERMS}

Gasification; gasifier; syngas; hydrogen; biomass; aspen plus; wood to hydrogen model; minimum hydrogen selling price; MHSP; economic analysis; DCFROR; H2A

\begin{tabular}{|l|l|l|l|l|}
\hline \multicolumn{2}{|l|}{ 16. SECURITY CLASSIFICATION OF: } & $\begin{array}{c}\text { 17. LIMITATION } \\
\text { OF ABSTRACT } \\
\text { a. REPORT } \\
\begin{array}{l}\text { Unclassified } \\
\text { Unclassified }\end{array}\end{array}$ & $\begin{array}{l}\text { c. THIS PAGE } \\
\text { Unclassified }\end{array}$ & $\begin{array}{c}\text { NUMBER } \\
\text { OF PAGES }\end{array}$ \\
\hline
\end{tabular}

19a. NAME OF RESPONSIBLE PERSON

19b. TELEPHONE NUMBER (Include area code) 